\title{
PENGARUH PENERAPAN PENDEKATAN PEMBELAJARAN SCIENTIFIC TERHADAP HASIL BELAJAR MATEMATIKA SISWA DI KELAS VIII
}

\author{
${ }^{1}$ Dita Yustika Septiyani, ${ }^{2}$ Nurul Astuty Yensy .B, ${ }^{3}$ Syafdi Maizora \\ 1,2,3 Program Studi Pendidikan Matematika JPMIPA FKIP Universitas Bengkulu \\ email: ${ }^{1}$ dita_yustikaseptiyani@yahoo.co.id, ${ }^{2}$ nurulastutyyensy@yahoo.com, \\ syafdiichiemaizora@unib.ac.id
}

\begin{abstract}
Abstrak
Penelitian ini bertujuan untuk mengetahui apakah ada pengaruh penerapan pendekatan scientific terhadap hasil belajar matematika siswa di kelas VIII SMPN 2 Kota Bengkulu. Penelitian ini merupakan penelitian eksperimen semu. Populasi dalam penelitian ini adalah siswa kelas VIII SMPN 2 Kota Bengkulu, dengan kelas VIIIA sebagai kelas eksperimen menggunakan pembelajaran dengan pendekatan saintifik dan kelas VIIIB sebagai kelas kontrol menggunakan pembelajaran konvensional. Teknik pengumpulan data dalam penelitian ini menggunakan instrumen tes hasil belajar (posttest) berupa soal essai. Berdasarkan hasil penelitian diperoleh nilai rata-rata hasil belajar siswa yang pembelajarannya menggunakan pendekatan scientifik lebih dari nilai rata-rata hasil belajar dengan menggunakan pembelajaran konvensional. Hal ini ditunjukkan dengan uji hipotesis menggunakan uji$\mathrm{t}$ diperoleh $\mathrm{t}_{\text {hitung }}=4,375$ dan $\mathrm{t}_{\text {tabel }}=1,994$ dengan $\alpha=0,05$. Karena nilai $\mathrm{t}_{\text {hitung }}>\mathrm{t}_{\text {tabel }}$ maka dapat disimpulkan bahwa terdapat pengaruh penerapan pendekatan pembelajaran scientifik terhadap hasil belajar matematika siswa di kelas VIII SMPN 2 Kota Bengkulu.
\end{abstract}

kata kunci : penelitian eksperimen, pendekatan scientifik, bangun ruang sisi datar.

\begin{abstract}
This study aims to determine whether there is influence the application of scientific approach to the results of learning mathematics students in class VIII SMPN 2 Bengkulu City. This research is a quasi-experimental research. The population in this study were students of class VIII Junior High School 2 Bengkulu City, with class VIIIA as experimental class using learning with scientific approach and class VIIIB as control class using conventional learning. Data collection techniques in this study using a test instrument of learning outcomes (posttest) in the form of essays. Based on the research results obtained the average value of student learning outcomes whose learning using a more scientific approach of the average value of learning outcomes by using conventional learning. This is shown by hypothesis test using t-test obtained $t_{\text {hitung }}=4,375$ and $t_{\text {tabel }}=1,994$ with $\alpha=0,05$. Because the value of $t_{\text {count }}>t_{\text {table }}$ then it can be concluded that there is influence of applying the approach of scientifik learning to the students' mathematics learning outcomes in class VIII Junior High School 2 Bengkulu City.
\end{abstract}

keywords: experimental research, scientific approach, flat space

\section{PENDAHULUAN}

Matematika merupakan salah satu cabang dari ilmu pengetahuan yang memiliki peranan penting dalam kehidupan manusia, dan menjadi dasar bagi ilmu-ilmu lain, seperti kimia, fisika, biologi, kedokteran, akuntansi, pertanian, dan ilmu lainnya, selain itu matematika juga memiliki banyak peranan dan dalam kehidupan sehari-hari. Oleh karena itu, matematika menjadi salah satu bidang studi yang diajarkan pada semua jenjang pendidikan. Salah satu hal yang membuat siswa merasa matematika itu adalah pelajaran yang sulit dan pelajaran yang membosankan karena strategi dan pendekatan yang dilaksankan oleh guru kurang tepat. 
Berdasarkan hasil wawancara dengan guru di SMP Negeri 2 Kota Bengkulu bahwa kurikulum yang digunakan adalah Kurikulum 2013, namun masih ada beberapa guru yang masih menggunakan pembelajaran konvensional.

Untuk meminimalisir masalah tersebut, salah satu upaya yang dapat dilakukan adalah dengan menerapkan suatu model atau pendekatan pembelajaran yang di indikasikan dapat meningkatkan hasil belajar matematika siswa. Menurut Susanto (2014:5) hasil belajar siswa adalah kemampuan yang diperoleh anak setelah melalui kegiatan belajar.

Salah satu pendekatan pembelajaran yang memungkinkan untuk meningkatkan hasil belajar matematika siswa adalah pendekatan scientific. MenurutDaryanto (2014:51) pendekatan pembelajaran saintifik adalah proses pembelajaran yang dirancang sedemikian rupa agar peserta didik secara aktif mengkonstruksi konsep, hukum atau prinsip melalui tahapantahapan mengamati (untuk mengidentifikasi atau menemukan masalah), merumuskan masalah, mangajukan atau merumuskan hipotesis, mengumpulkan data dengan berbagai teknik, menganalisis data, menarik kesimpulan, dan mengkomunikasikan konsep.

\section{METODE}

Jenis penelitian yang akan dilakukan adalah eksperimen semu atau quasi experimen. Menurut Sugiyono (2015:77) quasi experimen adalah penelitian yang mempunyai kelompok kontrol, tetapi tidak dapat berfungsi sepenuhnya untuk mengontrol variabel-variabel luar yang mempengaruhi pelaksanaan eksperimen.

\section{A. Populasi dan Sampel}

Populasi dalam penelitian ini adalah semua siswa kelas VIII SMP Negeri 2 Kota Bengkulu tahun ajaran 2016/2017. Teknik pengambilan sampel dalam penelitian ini menggunakan teknik Purposive Sampling. Berdasarkan nilai rata-rata hasil belajar kelas VIII, peneliti mengambil 2 kelas sampel yaitu kelas VIII A sebagai kelas eksperimen dengan menerapkan pembelajaran saintifik dan kelas VIII B sebagai kelas kontrol dengan diberikan perlakuan pembelajaran konvensional.

\section{B. Instrumen Penelitian}

Instrumen yang akan digunakan dalam penelitian ini adalah lembar tes hasil belajar yang diberikan dalam bentuk essay.

\section{Uji Validitas Soal}

Menurut Trianto (2011:269) validitas adalah suatu ukuran yang menunjukkan tingkat-tingkat kevalidan atau kesahihan sesuatu instrumen. Untuk mengukur validitas tes secara empirik dapat menggunakan rumus korelasi product moment dengan angka kasar yaitu :

$$
r_{x y}=\frac{N \sum X Y-\left(\sum X\right)\left(\sum Y\right)}{\sqrt{\left\{N \sum X^{2}-\left(\sum X\right)^{2}\right\}\left\{N \sum Y^{2}-\left(\sum Y\right)^{2}\right\}}}
$$

(Arikunto, 2005:72)

Keterangan :

$$
r_{x y}=\begin{aligned}
& \text { koefisien } \quad \text { korelasi } \\
& \text { antara variabel } \mathrm{X} \text { dan variabel }
\end{aligned}
$$

$\mathrm{Y}$, dua variabel yang dikorelasikan.

$\mathrm{N}=$ Jumlah siswa

$\mathrm{X}=$ Variabel bebas (skor item)

$\mathrm{Y}=$ Variabel terikat (skor total)

Dengan kriteria jika $r_{\text {hitung }}>r_{\text {tabel }}$ maka butir item tersebut valid.

\section{Uji Reliabilitas Soal}

Menurut Sudjana (2006:16) Reliabilitas alat penilaian adalah ketetapan atau keajegan alat tersebut dalam menilai apa yang dinilainya. Artinya, kapan pun alat penilaian tersebut digunakan akan memberikan hasil yang relatif sama. Reliabilitas tes hasil belajar dapat dihitung menggunakan rumus Alpha yaitu :

$$
r_{11}=\left(\frac{n}{n-1}\right)\left(1-\frac{\sum S_{i}^{2}}{S_{t}^{2}}\right)
$$

(Sudijono, 2012:208) 
Keterangan :

$$
\begin{aligned}
r_{11} & =\text { koefisien reliabilitas tes } \\
\mathrm{N} & =\text { banyaknya butir item yang } \\
& \text { dikeluarkan dalam tes }
\end{aligned}
$$

$\sum S_{i}^{2}=$ jumlah varian skor dari tiaptiap butir item

$S_{t}^{2} \quad=$ varian total

Selanjutnya dalam pemberian interpretasi terhadap koefisien reliabilitas tes $\left(r_{11}\right)$ pada umumnya digunakan patokan sebagai berikut

(Sudijono, 2012:209) :

1. Apabila $r_{11}$ sama dengan atau lebih besar daripada 0,70 bearti tes hasil belajar yang sedang diuji reliabilitasnya dinyatakan telah memiliki reliabilitas yang tinggi

(=reliable).

2. Apabila $r_{11}$ lebih kecil daripada 0,70 bearti tes hasil belajar yang sedang diuji reliabilitasnya dinyatakan belum memiliki reliabilitas yang tinggi (unreliable).

\section{Uji Taraf Kesukaran Soal}

Bermutu atau tidaknya butir-butir item tes hasil belajar pertama-tama dapat diketahui dari derajat kesukaran atau taraf kesulitan yang dimiliki oleh masing-masing butir item tersebut (Sudijono, 2012:370). Uji taraf kesukaran soal dimaksudkan untuk mengetahui soal-soal yang akan di uji adalah soal yang baik.

Angka indeks kesukaran item dapat diperoleh dengan menggunakan rumus yang dikemukakan oleh $\mathrm{Du}$ Bois, yaitu :

$$
\mathrm{P}=\frac{\mathrm{B}}{\mathrm{JS}}
$$

(Sudijono, 2012:372)

Keterangan :
$\mathrm{P}=$ Angka indeks kesukaran item.
$\mathrm{B}$ =Banyaknya siswa yang dapat menjawab dengan benar terhadap butir item yang bersangkutan.
JS =Jumlah seluruh siswa yang mengikuti tes hasil belajar.

Tabel 1. Kriteria Indeks Kesukaran

\begin{tabular}{|c|c|}
\hline Besarnya P & Interpretasi \\
\hline Kurang dari 0,30 & Terlalu Sukar \\
\hline $0,30-0,70$ & Cukup (Sedang) \\
\hline Lebih dari 0,70 & Terlalu Mudah \\
\hline
\end{tabular}

(Sumber : Sudijono, 2012:372)

\section{Uji Daya Beda Soal}

Menurut Sudijono (2012:385) daya pembeda item adalah kemampuan suatu butir item tes hasil belajar untuk dapat membedakan (mendiskriminasi) antara testee yang berkemampuan tinggi, dengan testee yang kemampuannya rendah.

Daya pembeda soal dapat diketahui dengan melihat besar kecilnya angka indeks diskriminan soal. Rumus untuk mencari daya beda adalah :

$$
D=\frac{B_{A}}{J_{A}}-\frac{B_{B}}{J_{B}}=P_{A}-P_{B}
$$

(Arikunto, 2005:213)

Keterangan :

$$
\begin{aligned}
\mathrm{J}= & \text { Jumlah peserta tes } \\
J_{A}= & \text { Banyak peserta kelompok atas } \\
J_{B}= & \text { Banyaknya peserta kelompok } \\
& \text { bawah } \\
B_{A}= & \text { Banyaknya peserta kelompok atas } \\
& \text { yang menjawab soal itu dengan } \\
& \text { benar } \\
B_{B}= & \text { Banyaknya peserta kelompok bawah } \\
& \text { yang menjawab soal itu dengan } \\
& \text { benar } \\
P_{A}= & \text { Proporsi peserta kelompok atas yang } \\
& \text { menjawab benar (ingat, P sebagai } \\
\text { indeks kesukaran) } & \text { Proporsi peserta kelompok bawah } \\
& \text { yang menjawab benar }
\end{aligned}
$$

Menurut Sudijono (2012:389) indeks diskriminasi item yang menjadi patokan pada umumnya adalah sebagai berikut : 
Tabel 2. Kriteria Daya Pembeda

\begin{tabular}{|c|c|}
\hline $\begin{array}{c}\text { Besarnya Angka } \\
\text { Indeks Diskriminasi } \\
\text { Item (D) }\end{array}$ & Interpretasi \\
\hline Kurang dari 0,20 & Jelek \\
\hline $0,20-0,40$ & Sedang \\
\hline $0,40-0,70$ & Baik \\
\hline $0,70-1,00$ & Baik sekali \\
\hline Bertanda negatif & Jelek sekali \\
\hline
\end{tabular}

(Sumber : Sudijono, 2012:389)

Kriteria soal yang dapat digunakan adalah jika indeks diskriminasi berkriteria sedang, baik, dan baik sekali

\section{Pengujian Persyaratan Analisis Uji Normalitas}

Uji normalitas dilakukan untuk mengetahui normal tidaknya suatu distribusi data. Rumus yang digunakan untuk uji normalitas data adalah uji chi kuadrat yaitu :

$$
X^{2}=\sum_{i=1}^{k} \frac{\left(f_{o}-f_{h}\right)^{2}}{f_{h}}
$$

(Sugiyono,

2012:107)

Keterangan :

$f_{o}=$ frekuensi yang diobservasi $f_{h}$

$=$ frekuensi yang diharapkan

$X^{2}=$ harga chi kuadrat

Kriteria pengujiannya adalah $X 2$ hitung $\leq X 2$ tabel dengan taraf nyata $5 \%$ $=0,05$ maka $\mathrm{H}_{0}$ diterima.

\section{Uji Homogenitas}

Uji homogenitas bertujuan untuk menguji apakah kedua kelompok sampel mempunyai varians yang sama atau tidak. Jika kedua kelompok mempunyai varians yang sama maka kedua kelompok dikatakan homogen. Uji homogenitas data menggunakan uji $\mathrm{F}$ yaitu :

$$
F=\frac{\text { Varians terbesar }}{\text { Varians terkecil }}
$$

dengan

$$
s^{2}=\frac{\sum\left(x_{i}-\bar{x}\right)^{2}}{n-1}
$$

(Sudjana, 2005:250)

Keterangan :

$$
\begin{aligned}
& s^{2}=\text { varians } \\
& \bar{x}=\text { rata- rata nilai sampel } \\
& n=\text { banyak sampel } \\
& x_{i}=\text { nilai data ke- } \mathrm{i}
\end{aligned}
$$

Kriteria pengujiannya adalah jika

$F_{\text {hitung }} \geq F_{\text {tabel }}$ maka $\mathrm{H}_{0}$ ditolak, dan jika $F_{\text {hitung }}<F_{\text {tabel }}$ maka H0 diterima. Dengan taraf nyata $5 \%$, dk pembilang $=\left(\mathrm{n}_{\mathrm{b}}-1\right)$ dan dk penyebut $=\left(n_{k}-1\right)$.

\section{Pengujian Hipotesis}

Untuk melakukan uji hipotesis digunakan uji-t untuk sampel independen (tidak berkorelasi).

Hipotesisnya sebagai berikut :

$$
\begin{aligned}
& H_{0}: \mu_{1}=\mu_{2} \\
& H_{1}: \mu_{1}>\mu_{2}
\end{aligned}
$$

Keterangan :

$\mu_{1}=$ Nilai rata-rata hasil belajar matematika siswa menggunakan pendekatan pembelajaran saintifik.

$$
\begin{aligned}
& \mu_{2}= \begin{array}{l}
\text { Nilai rata-rata hasil belajar } \\
\text { matematika siswa dengan }
\end{array} \\
& \text { pembelajaran konvensional. }
\end{aligned}
$$

Pengujian hipotesis menggunakan uji-t satu arah. Pengujian dilakukan dengan $\alpha=$ 0,05 dan dengan derajat kebebasan $(\mathrm{dk})=\left(n_{1}\right.$ $+n_{2}-2$ ). Rumus yang digunakan dalam melakukan uji-t satu arah (pihak kanan) menurut Sudjana (2005:239) adalah :

$$
t=\frac{\bar{x}_{1}-\bar{x}_{2}}{s \sqrt{\frac{1}{n_{1}}+\frac{1}{n_{2}}}}
$$


dengan

$$
s^{2}=\frac{\left(n_{1}-1\right) s_{1}^{2}+\left(n_{2}-1\right) s_{2}^{2}}{n_{1}+n_{2}-2}
$$

(Sudjana, 2005:239)

Keterangan :

$\overline{x_{1}}=$ Nilai rata-rata hasil belajar pada kelas eksperimen

$\overline{x_{2}}=$ Nilai rata-rata hasil belajar pada kelas kontrol

$n_{1}=$ Jumlah siswa pada kelas eksperimen

$n_{2}=$ Jumlah siswa pada kelas kontrol

$s^{2}=$ Variansi total (gabungan) hasil belajar pada kelas eksperimen dan kontrol

$s_{1}^{2}=$ Variansi hasil belajar pada kelas eksperimen

$S_{2}{ }^{2}=$ Variansi hasil belajar pada kelas kontrol Kriteria pengujian adalah : terima $\mathrm{H}_{0}$ jika $-t_{1-\frac{1}{2} \alpha}<t<t_{1-\frac{1}{2} \alpha \text { dimana }} t_{1-\frac{1}{2} \alpha}$ didapat dari daftar distribusi $\mathrm{t}$ dengan $\mathrm{dk}=$ $\left(n_{1}+n_{2}-2\right)$ dan tolak $\mathrm{H}_{0}$ jika thitung $>$ $t(1-\alpha)(d k)$ dengan $\alpha=0,05$.

\section{HASIL DAN PEMBAHASAN \\ Hasil Uji Coba Instrumen \\ 1. Hasil Uji Validitas}

Dari hasil perhitungan tingkat validitas yang terdiri dari 7 butir soal uraian hasilnya sebagai berikut :

Tabel 3.Rekap Hasil Perhitungan Korelasi Product Moment

\begin{tabular}{|c|l|l|c|}
\hline $\begin{array}{c}\text { Soal } \\
\text { Nomor }\end{array}$ & $\boldsymbol{r x y}$ & rtabel & Keterangan \\
\hline 1 & 0,916 & 0,344 & Valid \\
\hline 2 & 0,932 & 0,344 & Valid \\
\hline 3 & 0,824 & 0,344 & Valid \\
\hline 4 & 0,687 & 0,344 & Valid \\
\hline 5 & 0,884 & 0,344 & Valid \\
\hline 6 & 0,422 & 0,344 & Valid \\
\hline 7 & 0,731 & 0,344 & Valid \\
\hline
\end{tabular}

Berdasarkan tabel korelasi produk momen apabila rhitung > rtabel $(n=35)$ $=0,344$ dan taraf signifikan 5\%. Dengan demikian semua soal valid dan layak digunakan.

\section{Hasil Uji Reliabilitas}

Dari hasil perhitungan diperoleh nilai koefisien reliabilitas tes $\left(r_{11}\right)$ adalah 0,903 . Karena $r_{11}=0,903>0,70$ maka, soal tes tersebut reliabel atau dapat dipercaya.

\section{Hasil Uji Taraf Kesukaran}

Berikut hasil perhitungan uji taraf kesukaran :

Tabel 4. Rekap Hasil Uji Taraf Kesukaran

\begin{tabular}{|c|c|c|}
\hline $\begin{array}{c}\text { Soal } \\
\text { Nomor }\end{array}$ & $\begin{array}{c}\text { Indeks } \\
\text { Kesukaran }\end{array}$ & Keterangan \\
\hline 1 & 0,68 & Sedang \\
\hline 2 & 0,66 & Sedang \\
\hline 3 & 0,70 & Sedang \\
\hline 4 & 0,60 & Sedang \\
\hline 5 & 0,63 & Sedang \\
\hline 6 & 0,42 & Sedang \\
\hline 7 & 0,53 & Sedang \\
\hline
\end{tabular}

Karena semua item soal termasuk kategori sedang, maka semua soal dapat digunakan sebagai soal tes hasil belajar.

\section{Hasil Uji Daya Beda Soal}

Berdasarkan hasil perhitungan diperoleh bahwa tidak ada item soal yang memiliki daya beda negatif. Berikut hasil perhitungan uji daya beda soal.

Tabel 5. Rekap Hasil Perhitungan Daya Beda Soal

\begin{tabular}{|c|c|c|}
\hline $\begin{array}{c}\text { Soal } \\
\text { Nomor }\end{array}$ & $\begin{array}{c}\text { Daya } \\
\text { Beda }\end{array}$ & Keterangan \\
\hline 1 & 0,34 & Sedang \\
\hline 2 & 0,35 & Sedang \\
\hline 3 & 0,36 & Sedang \\
\hline 4 & 0,29 & Sedang \\
\hline 5 & 0,59 & Baik \\
\hline 6 & 0,36 & Sedang \\
\hline 7 & $\mathbf{0 , 1 9}$ & Jelek \\
\hline
\end{tabular}


Berdasarkan tabel 5. dapat dilihat soal yang tergolong sedang yaitu soal nomor 1, 2, 4 , dan 6 . Soal yang tergolong baik adalah soal nomor 3 dan 5. Sedangkan soal nomor 7 tergolong jelek karena mempunyai nilai kriteria < 0,20. Namun, dikarenakan soal nomor 7 termasuk valid, maka soal tetap dipakai.

\section{Analisis Deskriptif Hasil Penelitian \\ Kelas Eksperimen}

Tabel 6. Analisis Deskriptif Hasil Tes

Kelas Eksperimen

\begin{tabular}{|c|c|}
\hline Deskripsi & Nilai \\
\hline Jumlah Siswa & 36 \\
\hline Jumlah Nilai Siswa & 2708 \\
\hline Rata - rata & 75,22 \\
\hline Nilai Tertinggi & 95,00 \\
\hline Nilai Terendah & 49,00 \\
\hline Varians & 129,83 \\
\hline Simpangan Baku & 11,39 \\
\hline Skewness & $-0,41$ \\
\hline
\end{tabular}

Berdasarkan tabel 6. terlihat bahwa nilai rata - rata hasil tes belajar siswa yang diberikan dengan pendekatan saintifik yaitu sebesar 75,22, simpangan baku sebesar 11,39 dan rentang nilai siswa yang cukup jauh yaitu 46 dengan persentase ketuntasan klasikal siswa yaitu $72,2 \%$. Sedangkan nilai skewness sebesar -0,41 (mendekati 0) menunjukkan bahwa data hasil tes belajar siswa tersebut berdistribusi normal, dan dapat diperjelas oleh grafik kenormalan berikut.

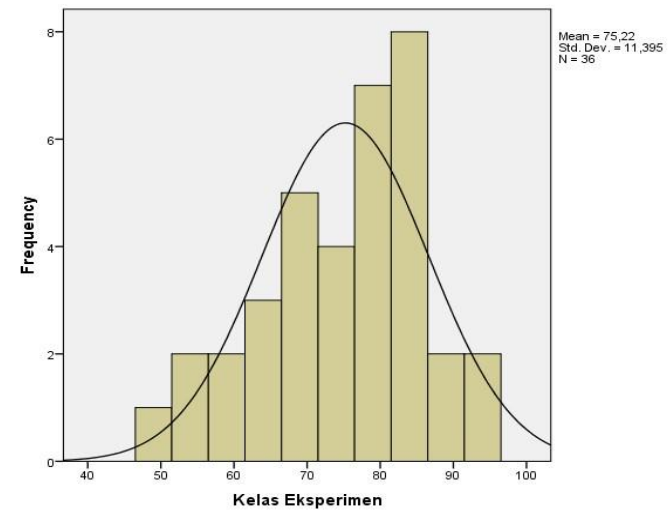

Gambar 1. Grafik Histogram Kelas Eksperimen

\section{Kelas Kontrol}

Tabel 7.Analisis DeskriptifHasil Tes Kelas Kontrol

\begin{tabular}{|c|c|}
\hline Deskripsi & Nilai \\
\hline Jumlah Siswa & 36 \\
\hline Jumlah Nilai Siswa & 2097 \\
\hline Rata - rata & 58,25 \\
\hline Nilai Tertinggi & 91,00 \\
\hline Nilai Terendah & 15,00 \\
\hline Varians & 411,85 \\
\hline Simpangan Baku & 20,29 \\
\hline Skewness & $-0,05$ \\
\hline
\end{tabular}

Berdasarkan tabel 7. terlihat bahwa nilai rata - rata hasil tes belajar siswa yang diberikan dengan pembelajaran konvensional yaitu sebesar 58,25, simpangan baku sebesar 20,29 dan rentang nilai siswa yang cukup jauh yaitu 76 dengan persentase ketuntasan klasikal siswa yaitu $27,8 \%$. Sedangkan nilai skewness sebesar -0,05 (mendekati 0) menunjukkan bahwa data hasil tes belajar siswa tersebut berdistribusi normal, dan dapat diperjelas oleh grafik kenormalan berikut.

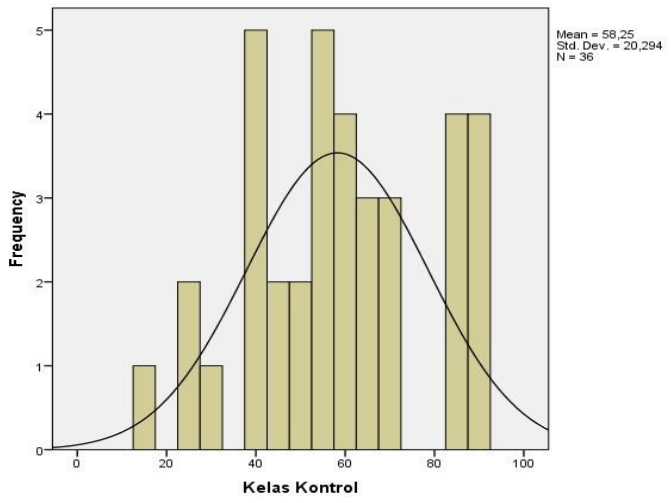

Gambar 2. Grafik Histogram Kelas Kontrol

Dapat disimpulkan bahwa berdasarkan tabel 6 dan tabel 7 terlihat secara deskriptif bahwa nilai rata - rata siswa kelas dengan pendekatan saintifik lebih dari nilai rata rata siswa kelas dengan pembelajaran 
konvensional. Sehingga, terdapat pengaruh penerapan pendekatan pembelajaran saintifik terhadap hasil belajar matematika pada materi bangun ruang sisi datar di kelas VIII SMPN 2 Kota Bengkulu.

\section{Analisis Prasyarat Uji Normalitas}

Rekapitulasi hasil uji normalitas kelas eksperimen dan kelas kontrol dengan pengujian chi-kuadrat sebagai berikut :

Tabel 8. RekapHasil Uji Chi - Kuadrat

\begin{tabular}{|c|c|c|c|}
\hline Kelas & $\begin{array}{l}\boldsymbol{\chi} \text { 2hitun } \\
\boldsymbol{g}\end{array}$ & $\begin{array}{c}\boldsymbol{\chi 2 t a b} \\
\boldsymbol{e l}\end{array}$ & $\begin{array}{c}\text { Keterang } \\
\text { an }\end{array}$ \\
\hline $\begin{array}{l}\text { Eksperim } \\
\text { en }\end{array}$ & 2,49 & 9,49 & $\begin{array}{c}\text { Data } \\
\text { berdistribu } \\
\text { si normal }\end{array}$ \\
\hline Kontrol & 7,27 & 9,49 & $\begin{array}{c}\text { Data } \\
\text { berdistribu } \\
\text { si normal }\end{array}$ \\
\hline
\end{tabular}

Berdasarkan tabel 8. dapat dilihat bahwa pada kelas eksperimen nilai $\chi 2$ hitung $=2,49$ dan $\chi 2$ tabel $=9,49$ maka $H_{0}$ diterima yang berarti data berdistribusi normal. Sedangkan pada kelas kontrol $\chi_{\text {hitung }}^{2}=7,27$ dan

$\chi_{\text {tabel }}^{2}=9,49$ maka $H_{0}$ diterima yang berarti data berdistribusi normal. Jadi, untuk kedua kelas data berdistribusi normal.

\section{Uji Homogenitas}

Rekapitulasi hasil uji normalitas kelas eksperimen dan kelas kontrol dengan pengujian Uji-F sebagai berikut : Tabel 9. RekapHasil Uji Homogenitas

\begin{tabular}{|c|c|c|c|}
\hline $\begin{array}{l}\text { Fhitun } \\
\boldsymbol{g}\end{array}$ & $\begin{array}{l}\text { Ftabe } \\
\boldsymbol{l}\end{array}$ & $\begin{array}{l}\text { Kesimpula } \\
\mathbf{n}\end{array}$ & $\begin{array}{c}\text { Keteranga } \\
\mathbf{n}\end{array}$ \\
\hline 3,17 & 1,76 & $H_{0}$ ditolak & $\begin{array}{l}\text { Varians } \\
\text { tidak } \\
\text { Homogen }\end{array}$ \\
\hline
\end{tabular}

Berdasarkan tabel 9. dapat dilihat bahwa nilai $F_{\text {hitung }}=3,17 \mathrm{dan} F_{\text {tabel }}=1,76$, karena $F_{\text {hitung }} \geq F_{\text {tabel }}$ maka $H_{0}$ ditolak berarti data tidak homogen.

\section{Uji Hipotesis}

Hipotesis yang diuji adalah :
$H_{0}$ :Nilai rata - rata matematika siswa

pendekatan pembelajaran saintifik sama dengan nilai rata - rata hasil belajar matematika siswa menggunakan pembelajaran konvensional di kelas VIII SMPN 2 Kota Bengkulu.

$H_{1}$ : Nilai rata - rata hasil belajar matematika siswa menggunakan pendekatan pembelajaran saintifik lebih dari nilai rata - rata hasil belajar matematika siswa menggunakan pembelajaran konvensional di kelas VIII SMPN 2 Kota Bengkulu.

Tabel 10. RekapHasil Uji-t untuk Sampel Independen

\begin{tabular}{|l|l|c|}
\hline thitung & ttabel & Keterangan \\
\hline 4,375 & 1,994 & $\begin{array}{c}H_{0} \text { ditolak } \\
\text { sehingga } H_{1} \\
\text { diterima. }\end{array}$ \\
\hline
\end{tabular}

Berdasarkan tabel 10. dapat dilihat bahwa nilai $t_{\text {hitung }}$ sebesar

4,375dan $t_{\text {tabel }}$ adalah 1,994, karena

$t_{\text {hitung }}>t_{\text {tabel }}$ maka $H_{0}$ ditolak. Maka, dapat disimpulkan bahwa terdapat pengaruh penerapan pendekatan pembelajaran saintifik terhadap hasil belajar matematika siswa di kelas VIII SMPN 2 Kota Bengkulu.

\section{PEMBAHASAN}

Hasil penelitian di SMPN 2 Kota Bengkulu kelas VIII pada materi bangun ruang sisi datar ini menunjukkan bahwa nilai rata-rata hasil belajar matematika siswa dengan menggunakan pendekatan saintifik lebih dari nilai rata-rata hasil belajar matematika siswa yang menggunakan pembelajaran konvensional secara deskriptif maupun secara pengujian hipotesis.

Hasil analisis deskriptif menunjukkan bahwa dengan standar KKM 71, pada kelas dengan pendekatan saintifik jumlah siswa yang tuntas sebanyak 24 orang atau sekitar $66,67 \%$ dan siswa yang tidak tuntas sebanyak 12 orang $(33,33 \%)$, sedangkan pada kelas dengan pembelajaran konvensional jumlah siswa yang tuntas sebanyak 9 orang atau sekitar $25 \%$ dan siswa yang tidak tuntas sebanyak 27 orang (75\%). Dapat disimpulkan dari persentase ketuntasan siswa bahwa kelas 
dengan pendekatan saintifik lebih dari persentase ketuntasan kelas dengan pembelajaran konvensional.

Selain itu, analisis hasil belajar siswa juga dapat dilihat dari banyaknya jawaban siswa yang menjawab soal dengan jawaban benar, jawaban salah dan tidak menjawab. Berikut akan ditunjukkan rekap soal tes akhir pada kelas eksperimen dan kelas kontrol :

Tabel 11.RekapBanyak Siswa yang Menjawab Soal Tes Akhir dengan Jawaban Benar (B), Jawaban Salah (S) dan Tidak Menjawab (TM)

\begin{tabular}{|c|c|c|c|c|c|c|}
\hline \multirow{2}{*}{$\begin{array}{c}\text { No } \\
\text { Soal }\end{array}$} & \multicolumn{3}{|c|}{$\begin{array}{c}\text { Kelas } \\
\text { Eksperimen }\end{array}$} & \multicolumn{3}{c|}{$\begin{array}{c}\text { Kelas Kontrol } \\
\text { yang Menjawab }\end{array}$} \\
\cline { 2 - 7 } & $\mathbf{3}$ & S & TM & \multicolumn{3}{|c}{$\begin{array}{c}\text { B } \\
\text { Menjang }\end{array}$} \\
\hline $\mathbf{1}$ & 36 & 0 & 0 & 26 & 10 & TM \\
\hline $\mathbf{2}$ & 35 & 0 & 1 & 33 & 2 & 1 \\
\hline $\mathbf{3}$ & 36 & 0 & 0 & 33 & 3 & 0 \\
\hline $\mathbf{4}$ & 35 & 1 & 0 & 33 & 3 & 0 \\
\hline $\mathbf{5}$ & 31 & 5 & 0 & 30 & 4 & 2 \\
\hline $\mathbf{6}$ & 30 & 6 & 0 & 22 & 11 & 3 \\
\hline $\mathbf{7}$ & 24 & 9 & 3 & 10 & 25 & 1 \\
\hline
\end{tabular}

Berdasarkan tabel 11. dapat dilihat bahwa pada soal nomor 1 mengenai unsurunsur balok, di kelas eksperimen semua siswa menjawab dengan benar, karena siswa dapat menyebutkan titik sudut, rusuk, sisi, diagonal bidang, diagonal ruang, dan bidang diagonal yang ada pada balok. Adapun contoh jawaban soal nomor satu siswa pada kelas eksperimen sebagai berikut :

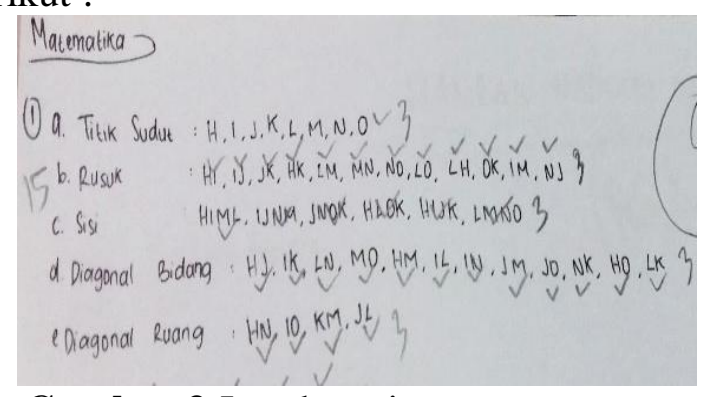

Gambar 3.Jawaban siswa nomor satu kelas eksperimen
Berdasarkan gambar 3. terlihat bahwa siswa sudah dapat memahami soal dan mampu menjawab sesuai dengan pertanyaan, walaupun beberapa siswa tidak mendapatkan poin penuh untuk soal nomor satu. Tetapi mereka telah mengetahui unsur-unsur bangun ruang sisi datar.

Sedangkan di kelas kontrol lebih dari setengah jumlah siswa yang menjawab soal dengan benar, siswa yang menjawab dengan benar ini adalah siswa yang telah memahami unsur-unsur bangun ruang sisi datar dan siswa yang menjawab salah, mereka masih belum memahami apa saja unsur-unsur bangun ruang sisi datar. Misalnya, antara diagonal bidang dan bidang diagonal siswa masih sering keliru dan siswa hanya menuliskan jumlah setiap unsur-unsur pada balok, tidak menyebutkan unsur-unsurnya. Adapun contoh jawaban soal nomor satu siswa pada kelas kontrol sebagai berikut :

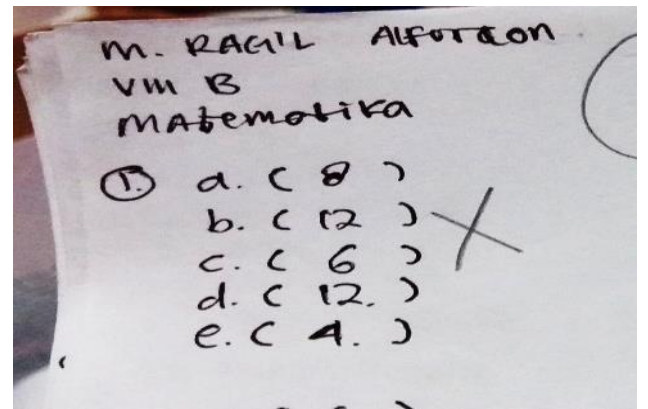

Gambar 4.Jawaban siswa nomor satu kelas kontrol

Berdasarkan gambar 4. terlihat bahwa ada siswa yang hanya menuliskan jumlah tiap unsur-unsur pada bangun ruang balok, tanpa menyebutkan namanya, dari sini terlihat bahwa siswa tidak memahami perintah dari soal.

Sedangkan, untuk soal nomor 5 mengenai volume dan luas permukaan kubus. Pada kelas eksperimen dan kelas kontrol hampir semua siswa menjawab dengan benar, siswa yang menjawab soal dengan benar adalah siswa yang telah memahami volume dan luas permukaan kubus dan mampu menyelesaikan soal dengan jawaban yang baik, sedangkan siswa yang menjawab salah masih belum mengerti 
pada bagian pengakaran untuk menemukan panjang sisi kubus, mereka masih belum tahu akar-akar kuadrat sempurna, dan di kelas kontrol siswa yang menjawab salah mereka tidak memahami soal, tidak mengerti proses penyelesaian soal, dan lupa rumus. Adapun contoh jawaban soal nomor lima siswa pada kelas eksperimen dan kelas kontrol sebagai berikut :
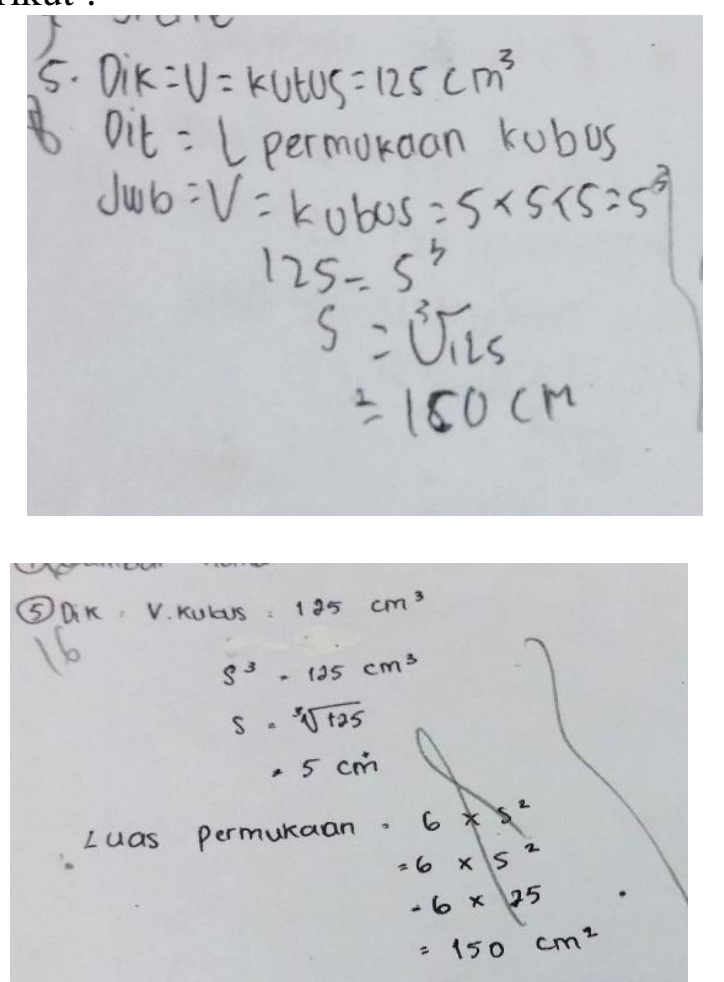

Gambar5. Jawaban siswa nomor lima kelas eksperiman
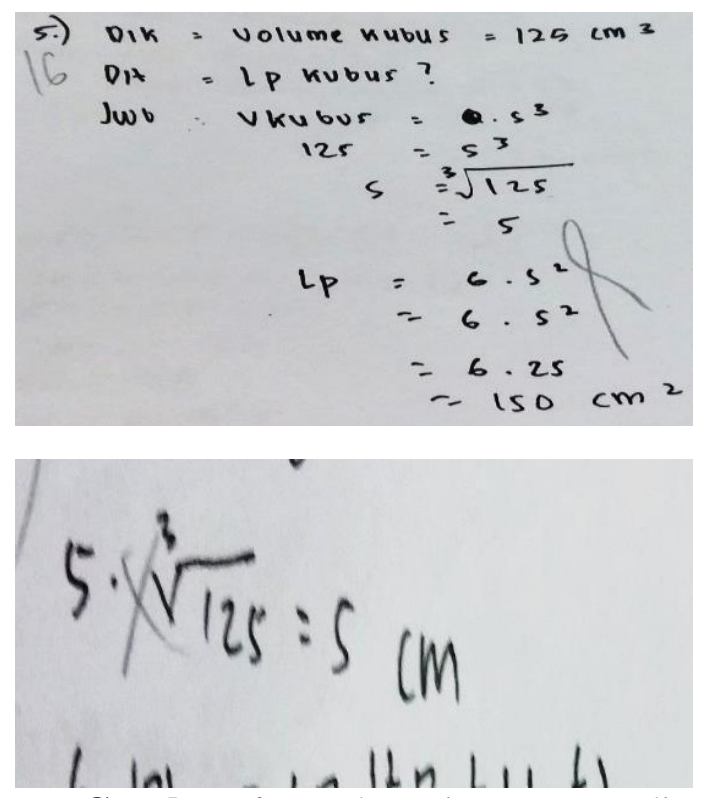

Gambar 6.Jawaban siswa nomor lima kelas kontrol

Berdasarkan gambar 5. terlihat bahwa siswa dapat mengerjakan soal mengenai volume dan luas permukaan kubus walaupun beberapa siswa masih ada yang kebingungan apa yang selanjutnya diselesaikan. Sedangkan, pada gambar 6. terlihat bahwa ada siswa yang mengerjakan soal dengan sembarangan, tidak paham apa yang harus dicari terlebih dahulu dan apa yang harus diselesaikan.

\section{PENUTUP \\ SIMPULAN}

Berdasarkan hasil penelitian di kelas VIII tahun ajaran 2016/2017 pada materi bangun ruang sisi datar SMPN 2 Kota Bengkulu, diperoleh hasil perhitungan

Uji-t nilai $t_{\text {hitung }}=4,375>t_{\text {tabel }}=1,994$, maka $H_{0}$ ditolak. Karena $H_{0}$ ditolak, artinya terdapat pengaruh penerapan pendekatan pembelajaran saintifik terhadap hasil belajar matematika siswa di kelas VIII SMPN 2 Kota Bengkulu.

\section{SARAN}

Saran yang dapat dikemukakan berdasarkan hasil penelitian sebagai berikut

1. Waktu penelitian harus terjadwal agar pembelajaran lebih efektif, seharusnya penelitian dapat dilakukan tiga kali pertemuan dalam satu minggu sesuai silabus.

2. Pada waktu melakukan uji coba soal, sebaiknya soal yang telah di uji coba langsung dianalisis.

\section{DAFTAR PUSTAKA}

Arikunto, Suharsimi. 2005. Dasar-dasar Evaluasi Pendidikan. Jakarta: Bumi Aksara

Sudijono, Anas. 2012. Pengantar Evaluasi Pendidikan. Jakarta: PT. Raja Grafindo Persada

Sudjana, Nana. 2006. Penilaian Hasil Proses Belajar Mengajar. Bandung: PT Remaja Rosdakarya 
Sudjana. 2005. Metoda Statistika.

Bandung: PT.Tarsito Bandung

Sugiyono. 2012. Statistika untuk

Penelitian. Bandung: Alfabeta

Sugiyono. 2015. Metode Penelitian

Kuantitatif, Kualitatif, dan $R \& D$.

Bandung: Alfabeta

Trianto. 2011. Pengantar Penelitian

Pendidikan Bagi Pengembangan

Profesi Pendidikan dan Tenaga

Kependidikan. Jakarta: Kencana 